\title{
Use of Underwater Acoustics in Marine Conservation and Policy: Previous Advances, Current Status, and Future Needs
}

\author{
Shane Guan ${ }^{1, *} \mathbb{D}$, Tiffini Brookens ${ }^{2, *}$ and Joseph Vignola ${ }^{1}$ \\ 1 Department of Mechanical Engineering, The Catholic University of America, Washington, DC 20064, USA; \\ vignola@cua.edu \\ 2 U.S. Marine Mammal Commission, Bethesda, MD 20814, USA \\ * Correspondence: guan@cua.edu (S.G.); tbrookens@mmc.gov (T.B.)
}

Citation: Guan, S.; Brookens, T.;

Vignola, J. Use of Underwater

Acoustics in Marine Conservation and Policy: Previous Advances, Current Status, and Future Needs. J. Mar. Sci. Eng. 2021, 9, 173. https:// doi.org/10.3390/jmse9020173

Academic Editors: Philippe Blondel and Michel André

Received: 19 December 2020

Accepted: 2 February 2021

Published: 9 February 2021

Publisher's Note: MDPI stays neutral with regard to jurisdictional claims in published maps and institutional affiliations.

Copyright: (c) 2021 by the authors. Licensee MDPI, Basel, Switzerland. This article is an open access article distributed under the terms and conditions of the Creative Commons Attribution (CC BY) license (https:// creativecommons.org/licenses/by/ $4.0 /)$.
Abstract: The interdisciplinary field of assessing the impacts of sound on marine life has benefited largely from the advancement of underwater acoustics that occurred after World War II. Acoustic parameters widely used in underwater acoustics were redefined to quantify sound levels relevant to animal audiometric variables, both at the source and receiver. The fundamental approach for assessing the impacts of sound uses a source-pathway-receiver model based on the one-way sonar equation, and most numerical sound propagation models can be used to predict received levels at marine animals that are potentially exposed. However, significant information gaps still exist in terms of sound source characterization and propagation that are strongly coupled with the type and layering of the underlying substrate(s). Additional challenges include the lack of easy-to-use propagation models and animal-specific statistical detection models, as well as a lack of adequate training of regulatory entities in underwater acoustics.

Keywords: underwater acoustics; underwater sound impacts; marine conservation; impact assessment

\section{Introduction-Historical Perspective}

As a visually oriented species, it is not surprising that our knowledge of the world has been based largely on reasoning and experimentation through visual means. This includes research on marine organisms whose natural habitats beneath the ocean surface are mostly beyond visual observation, e.g., [1,2]. Moreover, the lack of an auditory system that functions efficiently underwater led humankind to consider the marine environment as a "silent world" for eons, e.g., [3].

The need for navigational safety, especially after the sinking of the HMS Titanic as a result of striking an iceberg in the North Atlantic Ocean, and to detect enemy submarines (i.e., antisubmarine warfare or ASW) and warships during the two world wars prompted tremendous advancements in the field of underwater acoustics between the 1910s and 1950s [4,5]. However, it was not until the discovery of underwater sound production and orientation [6-8] and communication $[9,10]$ in several cetacean species that marine biologists began to investigate the potential effects of underwater sound on marine mammals.

While it was widely recognized before the 1970s that high sound levels, either from elevated ambient sound or from sonar ping reverberation, could adversely affect signal detection in the naval sonar community [4,5], Payne and Webb [11] were the first to document that long-distance acoustic communication ranges could be greatly reduced as a result of increased background sound levels from ships. By using simple sonar equations, Payne and Webb [11] determined that, with the advent of propeller-driven ships, the transmission range of $20-\mathrm{Hz}$ fin whale calls was reduced by nearly 100 and $3000 \mathrm{nmi}$ using spherical and cylindrical spreading models, respectively.

Some of the greatest achievements in environmental conservation in the United States occurred in the 1970s with the enactment of various laws, including passage of 
the Marine Mammal Protection Act (MMPA) in 1972 and the Endangered Species Act (ESA) in 1973 [12-14]. Implementation of the MMPA led to strict regulations by U.S. Federal agencies to reduce the incidental taking of marine mammals, initially in regard to fishery bycatches $[15,16]$.

The need to implement measures to mitigate impacts on marine mammals from human activities beyond commercial fisheries led to many government-sponsored studies and workshops. For example, in the early 1980s through the 1990s, the U.S. Minerals Management Service (MMS, the predecessor of the current Bureau of Ocean Energy Management (BOEM)) funded several studies investigating disturbance of marine mammals from oil and gas development activities in the Arctic [17]. Many of those studies provided novel information on how underwater sound from various industrial activities affected marine mammals [18-21].

In the early to mid-1990s, two global oceanographic experiments became controversial based on the concern that the intense underwater sound used for climate research would harm whales [22]. The Heard Island Feasibility Test (HIFT) and the subsequent Acoustic Thermometry of Ocean Climate (ATOC) used sufficiently intense low-frequency signals to measure large-scale and long-term temperature changes in the upper ocean layers [23-25]. The acoustic signal used in HIFT had a source level of $221 \mathrm{~dB}$ re $1 \mu \mathrm{Pa}$ at $1 \mathrm{~m}$ with a center frequency of $57 \mathrm{~Hz}$ [24], while the signal used in ATOC operated at $420 \mathrm{~W}$ (or $197 \mathrm{~dB}$ re $1 \mu \mathrm{Pa}$ at $1 \mathrm{~m}$ ) and was centered at $75 \mathrm{~Hz}$ [26]. To address the concerns of potential impacts from the sound emitted, extensive field studies were conducted on marine mammals and other marine organisms, e.g., [27-32].

Besides industry and academia, the military - particularly, the naval communityproduces intense underwater sound for various purposes. The sound sources include naval sonars, live-fire munitions, and underwater detonations used during training and testing activities and ship shock trials. However, the acoustic impacts from those sources were not broadly known until the early 1990s [33]. The situation changed dramatically in the late-1990s to early 2000s when several marine mammal mass-stranding events occurred in areas where the U.S. and North Atlantic Treaty Organization (NATO) navies had conducted exercises involving the use of active sonars, e.g., [34-38]. Those stranding events received considerable attention from environmental organizations, academia, and the public, which led to a surge in field and laboratory studies that have greatly increased our knowledge regarding the impacts of sound on marine mammals, as well as other marine life, including fish and invertebrates, in the past two decades [39-43].

Although our understanding of the impacts of sound on marine organisms has increased, the regulatory community has struggled to evaluate and incorporate new findings and data into impact assessments and environmental policies in general [44]. Since assessing acoustic impacts on marine life is an interdisciplinary field, it requires that regulators and policymakers have knowledge and education in both underwater acoustics and marine biology [45]. Therefore, a solid understanding of physical principles in acoustics is imperative for assessing the impacts of underwater sound.

This paper addresses many of the physical principles in underwater acoustics that have been and currently are applied to the regulation and management of underwater sound and what information needs to be obtained in the future.

\section{Application of Underwater Acoustic Principles in Marine Conservation and Policy-Current Status}

Impact assessments of various anthropogenic sound-generating activities involve the evaluation of the physical characteristics of the sound sources and the propagation of sound in the marine environment. Most of the concepts used in these assessments are based on the field of underwater acoustics. These include acoustic parameters, the characterization of underwater sources (measurements and modeling), the application of the sonar equation, and sound propagation modeling. 


\subsection{Acoustic Parameters}

A number of physical quantities can be used to describe underwater sound in terms of acoustic energy (in joules), power (in watts), intensity (in watts per unit area), and pressure (in pascals or micropascals or $\mu \mathrm{Pa}$ ). However, more commonly, the quantity of sound is expressed in a relative unit of decibels (dB), which is a logarithm (base 10) ratio of a physical quantity to a reference quantity, as expressed in the following equation:

$$
\mathrm{SPL}=10 \log _{10}\left(\frac{p}{p_{0}}\right)^{2}
$$

where SPL is the sound pressure level, $p$ is the acoustic pressure, and $p_{0}$ is the reference acoustic pressure.

This expression converts the physical unit to a "level". For example, the sound pressure (in $\mu \mathrm{Pa}$ ) can be expressed in the sound pressure level (SPL) in $\mathrm{dB}$ in reference to $1 \mu \mathrm{Pa}(\mathrm{dB}$ re $1 \mu \mathrm{Pa})$, which is the standard reference unit in underwater acoustics. For airborne sound, the standard referenced sound pressure level is $20 \mu \mathrm{Pa}$. The mismatch of acoustic impedance between water and air due to the differences in the sound speeds of these two media results in different acoustic pressures from a source with the same acoustic intensity. Specifically, for a plane wave with a far-field intensity of $I$, the underwater acoustic pressure $p_{w}$ and airborne acoustic pressure $p_{a}$ are

$$
\begin{aligned}
p_{w} & =\sqrt{I \rho_{w} c_{w}} \\
p_{a} & =\sqrt{I \rho_{a} c_{a}}
\end{aligned}
$$

where $c_{w}$ and $c_{a}$ are the sound speed in water and air, and $\rho_{w}$ and $\rho_{a}$ are the density of water and air, respectively. The product $\rho c$ is referred to as a characteristic acoustic impedance. Given that the nominal sound speed in water is $1500 \mathrm{~m} / \mathrm{s}$, the nominal sound speed in air is $340 \mathrm{~m} / \mathrm{s}$, the density of water is about $1000 \mathrm{~kg} / \mathrm{m}^{3}$, and the density of air is about $1.225 \mathrm{~kg} / \mathrm{m}^{3}$, the underwater acoustic pressure from a sound source with the same intensity would be approximately 60 times great than that in the air.

For example, for a sound source with an intensity of $1 \mathrm{~W} / \mathrm{m}^{2}$, the underwater and airborne acoustic pressures would be approximately $1225 \mathrm{~Pa}$ and $20 \mathrm{~Pa}$, respectively, based on Equation (2), and the underwater and airborne SPLs would be $182 \mathrm{~dB}$ re $1 \mu \mathrm{Pa}$ and $120 \mathrm{~dB}$ re $20 \mu \mathrm{Pa}$, respectively. These issues often create confusion among lay persons and regulators who may not be well-versed in physical acoustics [46].

Notwithstanding the simple definition of SPL provided herein, several variations of broadband "sound levels" are tailored to address different types of source characteristics that are pertinent to various marine organisms that have different vibroacoustic sensitivities $^{1}$ and exhibit varying responses $[47,48]$. Some of the commonly used sound levels are the peak sound pressure level $\left(L_{\mathrm{pk}}, L_{0-\mathrm{pk}}\right.$, or SPL $\left.L_{\mathrm{pk}}\right)$; root mean square (rms) sound pressure level ( $L_{\mathrm{p}, \mathrm{rms}}$ or SPL $\left.\mathrm{rms}_{\mathrm{rm}}\right)$; sound exposure level ( $L_{\mathrm{E}}$ or SEL)l single-strike (single-shot or single-ping) sound exposure level $\left(L_{\mathrm{E}, \mathrm{ss}}, L_{\mathrm{E}, \mathrm{sp}}\right.$, or $\left.S E L_{\mathrm{ss}}\right)$; and cumulative sound exposure level $\left(L_{\mathrm{E}, \mathrm{cum}}\right.$ or $\left.\mathrm{SEL}_{\mathrm{cum}}\right)$. The usage of these sound level metrics is summarized in Table 1.

1 The authors acknowledge the importance of particle motion. However, particle motion, velocity, and acceleration are beyond the scope of this paper. Please see $[47,48]$ for more details regarding particle motion. 
Table 1. Summary of the sound level metrics commonly used in assessing the impacts of underwater sound on marine life.

\begin{tabular}{ccc}
\hline Metric \& Notation & Equation for Derivation & \multicolumn{1}{c}{ Usage in Impact Assessment } \\
\hline & & $\begin{array}{l}\text { The maximum instantaneous sound pressure, } \\
\text { which is used to assess a potential permanent } \\
\text { threshold shift (PTS) and temporary threshold } \\
\text { shift (TTS) in the hearing of marine mammals }\end{array}$ \\
$\begin{array}{c}\text { Peak sound pressure level }\left(L_{\mathrm{pk}}, L_{0-\mathrm{pk}},\right. \\
\left.\text { or SPL } L_{\mathrm{pk}}\right)\end{array}$ & $L_{\mathrm{pk}}=10 \log _{10}\left(\frac{p_{\mathrm{pk}}}{p_{0}}\right)^{2}$ & mammals [52], and mortality and injury in fish \\
& & and sea turtles [53] exposed to impulsive sound.
\end{tabular}

The square root of the average of the sound pressure squared over a given duration, which is used to assess potential behavioral disturbance in marine mammals [54] from impulsive and

Root-mean-square sound pressure level ( $L_{\mathrm{p}, \mathrm{rms}}$ or SPL $\left.\mathrm{rms}_{\mathrm{s}}\right)$

$$
L_{\mathrm{p}, \mathrm{rms}}=10 \log _{10}\left[\frac{1}{T} \int_{T} \frac{p^{2}(t)}{p_{0}^{2}} \mathrm{~d} t\right]
$$
non-impulsive sound exposure-a time window that consists of $90 \%$ of the acoustic energy is used to calculate $L_{\mathrm{p}, \mathrm{rms}}$ for impulsive sound [55]. It also is used to assess the potential mortality, injury, or TTS in fish and sea turtles exposed to non-impulsive sound [53].

\begin{tabular}{|c|c|c|}
\hline Sound exposure level ( $L_{\mathrm{E}}$ or SEL) & $L_{\mathrm{E}}=10 \log _{10}\left[\frac{1}{T_{0}} \int_{T_{100}} \frac{p^{2}(t)}{p_{0}^{2}} \mathrm{~d} t\right]$ & $\begin{array}{l}\text { A 1-s normalized } L_{E} \text { is used to characterize the } \\
\text { source level for non-impulsive sound [56]. }\end{array}$ \\
\hline $\begin{array}{l}\text { Single-strike, single-shot, single-ping } \\
\text { sound exposure level }\left(L_{\mathrm{E}, \mathrm{ss}}, L_{\mathrm{E}, \mathrm{sp}}\right. \\
{\left.\text { or } \mathrm{SEL}_{\mathrm{ss}}\right)}\end{array}$ & $L_{\mathrm{E}, \mathrm{ss}}=10 \log _{10}\left[\int_{T_{100}} \frac{p^{2}(t)}{p_{0}^{2}} \mathrm{~d} t\right]$ & $\begin{array}{l}\text { For impulsive or non-impulsive intermittent } \\
\text { sounds, this is the } L_{E} \text { for a single hammer strike } \\
\text { for pile driving }[56,57] \text {, a single air gun shot for a } \\
\text { seismic survey, or a single ping for sonar. }\end{array}$ \\
\hline $\begin{array}{l}\text { Cumulative sound exposure level } \\
\qquad\left(L_{\mathrm{E}, \mathrm{cum}} \text { or } \mathrm{SEL} L_{\text {cum }}\right)\end{array}$ & $L_{\mathrm{E}, \mathrm{cum}}=10 \log _{10}\left[\int_{T_{\text {cum }}} \frac{p^{2}(t)}{p_{0}^{2}} \mathrm{~d} t\right]$ & $\begin{array}{l}\text { This is the } L_{E} \text { for the entire duration of sound } \\
\text { exposure. It is used to assess potential PTS and } \\
\text { TTS in marine mammals when exposed to } \\
\text { impulsive or non-impulsive sounds [49-51] and } \\
\text { the mortality or injury of fish and sea turtles } \\
\text { exposed to impulsive sound [53]. }\end{array}$ \\
\hline
\end{tabular}

Notation: $p_{\mathrm{pk}}=$ peak acoustic pressure in a time series, $p(t)=$ time varying acoustic pressure in a waveform, $p_{0}=$ referenced acoustic pressure, which is $1 \mu \mathrm{Pa}, T=$ duration of the time series, $T_{100}=$ the entire $(100 \%)$ time duration of the time series, $T_{0}=$ a referenced time interval of $1 \mathrm{~s}$, and $T_{\text {cum }}=$ the entire duration of sound exposure.

\subsection{Source Characterization}

In acoustics, a source is a physical device or object that generates acoustic disturbance(s) in a medium. A simple point source can be viewed as a pulsating sphere with its radius varying sinusoidally with time. The acoustic pressure generated by such a sphere is time-varying and contains one or more frequencies.

Similar to almost all real-world sources, very few anthropogenic sources can be treated as a simple point source. Sound sources that have routinely been evaluated for adverse impacts on marine mammals include seismic air guns, military sonars, various types of in-water pile driving, underwater detonations, drilling, and, to some extent, civilian sonars and high-resolution geophysical (HRG) devices. Although it is well-recognized that vessel noise is the most pervasive source of anthropogenic sound both in terms of temporal and spatial extents in the marine environment [58,59], its potential impacts are not well-addressed, nor is it currently regulated in most countries. Additionally, with the exception of certain military and civilian sonars, the majority of these sound sources are considered broadband.

Based on the temporal characteristics and the types of impacts ${ }^{2}$, underwater sound sources are classified by the following categories: impulsive, non-impulsive, continuous,

2 In the U.S. regulatory framework, impacts on marine mammals are classified into two categories: Level A harassment, which has the potential to cause injury, and Level B harassment, which has the potential to cause behavioral disturbance, as well as temporary threshold shifts (TTS). 
and intermittent. It should be noted that the definitions of these four categories within the regulatory community generally are qualitative, although quantitative methods have been proposed in a few cases when clear-cut distinctions between categories are evident. For example, when differentiating between impulsive and non-impulsive sources, a 3-dB difference in measurements between the continuous and impulse settings of a sound level meter (SLM) has been used [57]. Specifically, if the SLM measurement from the impulse setting (a 35-ms window) is $3 \mathrm{~dB}$ or greater than the continuous setting (a 1-s window), the sound should be classified as impulsive [60]. A recent study by Martin et al. [61] used the kurtosis of a 1-min time window to determine whether a sound was impulsive or non-impulsive.

However, not all of these categories are mutually exclusive. For example, a source that is impulsive is typically intermittent (e.g., impact pile driving), but a source that is nonimpulsive can be either continuous (e.g., vibratory pile driving and removal) or intermittent (e.g., sonar). In addition, not all sources fit into a single category. For example, downthe-hole (DTH) pile installation produces both percussive hammering and continuous drilling sounds, while HRG devices can emit impulsive or non-impulsive intermittent sounds. Some common examples of the source categories used by the U.S. regulatory community are provided in Table 2. An explanation of how these different categories of sound sources should be analyzed under the MMPA is provided in a User Spreadsheet Tool by the National Marine Fisheries Service $[62]^{3}$.

Table 2. Examples of common categories of sound sources regulated by the U.S. regulatory community.

\begin{tabular}{ccc}
\hline Source Type & For Assessing PTS and TTS & $\begin{array}{c}\text { For Assessing Behavioral } \\
\text { Disturbance }\end{array}$ \\
\hline Seismic air gun & Impulsive & Intermittent \\
\hline Impact pile driving & Impulsive & Intermittent \\
\hline Underwater detonations & Impulsive & Intermittent \\
\hline $\begin{array}{c}\text { Vibratory pile driving and } \\
\text { removal }\end{array}$ & Non-impulsive & Continuous \\
\hline DTH pile installation & Impulsive and non-impulsive & Intermittent and continuous \\
\hline Sonar & Non-impulsive & Intermittent \\
\hline HRG devices & Non-impulsive and impulsive & Intermittent \\
\hline Drilling & Non-impulsive & Continuous \\
\hline Icebreaking & Non-impulsive & Continuous
\end{tabular}

Notation: DTH = down-the-hole and HRG = high-resolution geophysical.

For the most part, source levels are based on broadband sound levels measured at given locations back-calculated to $1 \mathrm{~m}$ from the source or modeled (in which case, the spectra also are considered). For in-water pile driving for construction activities, the term "source level" used by the regulatory community in the United States typically refers to the broadband sound level ( $L_{\mathrm{pk}}, L_{\mathrm{p}, \mathrm{rms}}$, or $\left.L_{\mathrm{E}, \mathrm{ss}}\right)$ measured at or normalized to $10 \mathrm{~m}$ as opposed to the more conventional $1 \mathrm{~m}$ from the pile, e.g., [56]. For seismic air guns, source levels are obtained from in situ measurements at various distances back-calculated to $1 \mathrm{~m}$ from the source, e.g., [63-67]. For many sources for which measurements are not available, source models (e.g., Gundalf, Nucleus, and Airgun Array Source Model (AASM)) are used to estimate the source levels that then are fed into sound propagation models, e.g., [68].

3 The User Spreadsheet Tool is available at https://media.fisheries.noaa.gov/2020-12/2020_BLANK_USER_SPREADSHEET_-508_DEC.xlsx?null (accessed on 2 February 2021). 


\subsection{Sound Propagation}

As with all underwater acoustic analyses, the basic sonar equation with only the geometric spreading loss term is most commonly used by conservation biologists and regulators to estimate received sound levels. That equation is expressed in $\mathrm{dB}$ as

$$
\mathrm{TL}=F \log _{10}(R)
$$

where TL is the transmission (or propagation) ${ }^{4}$ loss [4,45,69-72], $F$ is a coefficient for the $\mathrm{TL}$, and $R$ is the distance from the source to receiver (i.e., the animal). For a simple point source within a lossless infinite medium, $F$ is 20 , which implies the "spherical spreading" of acoustic energy. In a shallow-water environment, the boundary condition dictates that the acoustic energy predominantly follows a "cylindrical spreading" model, where the transmission loss would be expressed as $10 \log (R)[4,69]$. In addition, there is a "combined spreading loss" model that calculates transmission loss using spherical spreading to a certain range $H$ where the sound reaches the sea floor-after which, cylindrical spreading is assumed [73].

The combined spreading loss is expressed as

$$
\mathrm{TL}=20 \log _{10}(H)+10 \log _{10}\left(\frac{R}{H}\right)
$$

at a range $(R)$ greater than the water depth $(H)$. Although additional loss mechanisms such as absorption and scattering (i.e., volume and boundary scattering) also contribute to the decay of acoustic intensity over range, models that incorporate absorption and scattering terms are seldom used by regulators, mainly due to the fact that such models cannot be solved analytically. Similarly, transmission loss models that incorporate low-frequency cutoffs or leakages in shallow water also are rarely used by regulators.

To account for the additional losses due to absorption and scattering, and to partially account for acoustic energy that is confined within the boundaries, regulatory agencies often use 15 (i.e., the arithmetic mean between 20 and 10) as the transmission loss coefficient and define it as "practical spreading". The practical spreading model primarily is used to assess the impacts from pile-driving activities, e.g., [74]. Other transmission loss coefficients that have been used include the derivation of decay slopes from linear fit models of field measurements at varying distances, e.g., [75]. However, transmission loss coefficients obtained using field measurements are location- and season-specific, because received sound levels at distances from the source are products of multiple attenuation mechanisms. Factors such as sediment type, bathymetry, and temperature/salinity profiles of the water column often dictate far-field sound level measurements.

However, sophisticated numerical sound propagation models (such as ray theory, wavenumber integration, normal mode, the parabolic equation, etc.; see [69]) generally are not used by the regulatory community. Regulatory agencies typically rely on results provided by applicants or their contractors who have those modeling capabilities, e.g., $[76,77]$. In those cases, it sometimes is unclear whether the regulatory agencies adequately evaluated or validated the modeling results.

\subsection{Impact Assessment Analyses}

In general, the underlying approach for assessing the impacts of underwater sound on marine life uses a source-path-receiver model, where the source is the anthropogenic sound emitted, the path describes the assumed sound propagation, and the receiver is the animal(s) that detects the sound.

4 The authors recognize the difference between "transmission" and "propagation" under certain circumstances, where "transmission" could mean traveling of the acoustic wave from one medium to another. However, these two terms are used interchangeable herein, because the term "TL" is more widely used for "transmission loss" than "PL" for "propagation loss" in the underwater acoustics literature; see [4,45,70-73]. 
This model can be best presented in the form of a simple passive sonar equation:

$$
\mathrm{RL}=\mathrm{SL}-\mathrm{TL}
$$

where $\mathrm{RL}^{5}$ is echo level or received level, SL is source level, and TL is transmission loss $[4,71]$.

The metrics used for received levels mirror those of acoustic parameters described herein; however, the numerical values of the levels, or thresholds, have been revised, as more studies have been conducted investigating the acoustic impacts of underwater sound. For example, the auditory injury thresholds (defined as permanent threshold shift (PTS)) were revised from the $L_{\mathrm{p}, \mathrm{rms}}$ thresholds of 180 - and 190- $\mathrm{dB}$ re $1 \mu \mathrm{Pa}$ for cetaceans and pinnipeds, respectively [54], to the dual criteria of $L_{\mathrm{E}, \mathrm{cum}}$ and $L_{\mathrm{p}, \mathrm{pk}}$, with the incorporation of frequency-based, auditory weighting functions for the $L_{\mathrm{E}, \mathrm{cum}}$ metric $[49,50]$.

The receivers that are pertinent to impact assessment analyses include all aquatic organisms that are sensitive to underwater sound and vibroacoustic disturbance. The levels upon which adverse impacts occur depend on the taxonomy, physiology, and behavioral ecology of specific species or individual animals, which is not within the scope of this paper. Interested readers are referred to several research, review, and guidance papers for the relevant information, e.g., $[45,49-53,60,78]$.

The statistical detection theory at the receiver (i.e., the animal) is not currently considered in impact assessments of underwater sound. Such considerations would include quantitative studies of detection thresholds, the minimum signal-to-noise ratio needed to perceive the signal, the frequency spectrum and bandwidth of the signal, and the ambient sound, as well as receiver operating characteristic (ROC) curves, which describe the probability of detection at the receiver given a detection threshold and the signal-to-noise ratio [5].

Additionally, receiver (animal) movement modeling can be used to better inform an impact assessment by estimating the number of animals, in the form of "animats" that could be affected (taken). Animal movement modeling falls within the field of behavioral ecology; therefore, it is not discussed further. However, multiple animal movement models do exist; see [79] for information on the Marine Mammal Movement and Behavior (3MB) ${ }^{6}$ and [80] for information on the Navy Acoustic Effects Model (NAEMO).

\subsection{Chronic Impact Assessment and Soundscape Analyses}

Over the past decade or so, there has been increased interest in addressing potential chronic and cumulative impacts from low-intensity sound sources (e.g., commercial ships and smaller vessels) that are not typically regulated [81,82]. Many of these studies have shown that chronic exposure to low-intensity sound can cause various adverse effects, such as communication masking, changes in vocalizations and echolocation, and increased stress levels [83].

With the recent advances in underwater acoustic sensing technology available to nonmilitary researchers, the accessibility of large acoustic datasets from global sensor networks, and the enhanced computational resources for signal processing of large acoustic datasets, the large-scale, long-term monitoring of the underwater acoustic environment is feasible. These new opportunities have created considerable possibilities for studying the relationship between underwater acoustic and biological phenomena [84].

Many of these studies build on earlier research on ambient sound by analyzing spectral contents of long-term acoustic recordings. A frequency-time analysis has been used to investigate the inter-relationships of three sound types-biophony, geophony, and anthrophony-within an ecosystem. This relatively new subfield, ecoacoustics and

5 In most underwater acoustics literature, "EL" (echo level) is typically used to indicate the received (echo) level at the receiving transducer, and "RL" is reserved for the reverberation level in the sonar equation (e.g., $[5,60,70,73]$. However, this paper uses "RL" to indicate "received level", which is a more common practice within the ocean sound community (e.g., [39]).

6 3MB is available at http:/ / oalib.hlsresearch.com/Sound\%20and\%20Marine\%20Mammals/3MB\%20HTML.htm (accessed on 8 February 2021). 
soundscape ecology $[85,86]$, takes a holistic approach for studying underwater sound and their relationship to marine life. Ecoacoustics and soundscape ecology allow for the assessment of the overall health of the ecosystem by including the acoustic component, a very important element that has been long overlooked.

\subsection{Knowledge and Expertise of Regulatory Community}

The regulatory community that oversees the implementation of marine conservation and policy measures concerning the impacts of underwater sound primarily are composed of conservation biologists and environmental policy specialists, many of whom lack a formal educational background in physics, mathematics, or underwater acoustics. Staff analysts and managers who conduct impact assessments and make regulatory decisions may receive on-the-job training through seminars and web-based tutorials, such as those on the Discovery of Sound in the Sea website (https: / / dosits.org/, accessed on 2 February 2021). However, such ad hoc training is inadequate to bring analysts within the U.S. regulatory community beyond the level of performing simple analytical calculations of sound propagation using scripted spreadsheets. Few are able to evaluate sophisticated acoustic models or sound source measurements. The regulatory agencies have yet to prioritize the knowledge and skills of physical acoustics that are necessary to conduct impact assessments of underwater sound. These shortcomings have resulted in frequent errors, the omission of pertinent information, and inconsistencies in agency decision-making documents, as documented in multiple comment letters from the U.S. Marine Mammal Commission, an independent oversight agency, e.g., [87-96].

For example, when addressing the potential impacts of the relatively novel DTH pile installation method, one regulatory agency repeatedly mischaracterized the source, used inappropriate thresholds, and underestimated the source levels, which resulted in much smaller impact zones $[89,92-94]$. In another example, the same agency fabricated a method termed "log average of the sources" - taking a log average of log-based sound levels to derive a source level for DTH pile installation-which is not rooted in the principles of underwater acoustics [89]. The agencies also have routinely used inappropriate and inconsistent source levels for pile driving and removal, as well as inappropriate thresholds in general $[87,88]$ and inappropriate assumptions and inputs for estimating the extents of the various impact zones [89,91-93]. The aforementioned issues result in inaccurate and often underestimated impact zones, which are used to determine whether and how an animal may be affected and to inform the mitigation measures necessary to minimize those impacts.

\section{Needs for Using Underwater Acoustics in Marine Conservation}

While underwater acoustic concepts are well-understood, information gaps exist, and training is necessary to improve the accuracy of and consistency among impact assessments. Data and information needs include source characteristics of novel sound sources; robust and easy-to-use sound propagation models; and statistical detection models, as well as quantitative exposure models that evaluate the acute, chronic, and cumulative impacts on marine organisms. While the last topic is addressed primarily by the field of bioacoustics, the knowledge of behavioral ecology and physiology needs to be incorporated into any impact assessment [38] and is beyond the scope of this paper. The research needs regarding source characterization, propagation modeling, and detection theory are provided herein.

\subsection{Source Characterization}

Despite the numerous technical reports that involve measurements of underwater sound generated by various sound sources, robust data are still lacking concerning some of the sound sources. Those deficiencies include: (1) novel sound sources, (2) uncommon sources for which few data exist, and (3) a lack of scientific rigor in measurements. Large variations in source levels also are evident among the same source type, which adds another complicating factor. 
Some sound sources are novel, which either have not been used in the marine environment until recently or have not been well-documented. For example, in-water pile installation using DTH pile installation is a relatively new application in the marine environment and uses a combination of percussive and drilling mechanisms [57]. During DTH pile installation, a percussive hammer acts directly upon the bedrock to create a hole for the pile to enter, while the drill cuttings and debris at the rock surface are removed by an airlift exhaust through the inside of a pile. Therefore, the sound generated from DTH pile installation contains both impulsive, intermittent components (from percussive hammer strikes) and non-impulsive, continuous components (from drilling actions and airlifts of debris). Currently, only a few studies have conducted measurements of DTH pile installations [57,97-101]. Additionally, in situ measurements of DTH pile installations have been limited to piles with diameters of only $0.20 \mathrm{~m}, 0.46 \mathrm{~m}, 0.61 \mathrm{~m}$, and $1.07 \mathrm{~m}$. Those data are scant and inadequate, particularly for larger-sized piles. Piles used in coastal construction projects can be larger and are generally much larger for offshore wind turbine structures. In addition, the substrates associated with the measured sound levels often are not specified.

Other sound sources that lack the full complement of the relevant acoustic information include various nonmilitary shipboard or towed sonars, transducers, other HRG sources, and acoustic deterrent devices. While potential effects from exposure to these sources are still under debate due to their generally lower intensity and high-frequency components (which are subject to greater absorption losses) [102-105], the source levels of these devices have not been well-documented beyond the manufacturer specifications, e.g., [106].

There also are new sources that are being developed. One example is marine vibroseis, a source that is being developed to replace a conventional air gun array with much reduced SPLs [107-109]. Source characteristics of marine vibroseis are mostly modeled; there are few in situ measurements of sound levels of marine vibroseis to date [110].

While a number of models were developed and countless measurements were made for open-water underwater detonations years ago (as one of the sound sources for underwater acoustics research was small charges), e.g., [4,111-114], few studies are available on sound characteristics and propagation from detonations that are embedded in bedrock or other structures, e.g., $[115,116]$. The lack of measurements from confined underwater detonations presents significant challenges when assessing environmental impacts for projects that use such methods, particularly for shipping channel deepening or structure removal.

Conversely, sound generated from marine seismic surveys using air guns have been well-documented since the 1980s [45]. Numerous measurements of seismic air gun arrays have been acquired in the Arctic for the purpose of environmental compliance from the mid2000s to early 2010s, e.g., [63-67,117-119]. Nevertheless, due to differences in the volumes of air gun arrays and their deployment configurations, those measurements were only pertinent to those specific surveys. Industrial standard models such as Gundalf $[120,121]$, Nucleus [122], and AASM [123] have been used to predict air gun array sound levels to form the sound propagation modeling used in impact assessments; however, none of the models are available to the regulatory community for use at this time. In addition, the accuracy of these models is still being evaluated by the underwater acoustic modeling community, e.g., [124,125].

Similar issues exist for in-water pile-driving data. Despite the fact that large quantities of pile-driving sound level measurements exist, e.g., [56], the regulatory community has struggled to use representative source levels consistently for specific pile materials and dimensions. Some of the inconsistencies are due to differences in bathymetry, substrate type, hammer energy, and other environmental parameters at the locations where measurements have been collected. An attempt is underway by one of the authors to review and analyze all available pile-driving measurement data and to recommend a set of "generic" 10-m normalized source levels based on the various pile types and diameters. Similar to air gun source models, models for pile-driving sound sources also exist, e.g., [126-128]. None 
of these models are readily available for use by the regulatory community to form its environmental impact assessments.

In addition to the need to characterize broadband levels from many of the aforementioned sound sources, spectral information regarding these sources is in demand, as impact assessments of auditory effects are often frequency-dependent, especially for marine mammals [50].

Finally, most sound level measurements have been conducted for the purpose of environmental compliance and were collected and analyzed by contractors of regulated entities with varying professional experience and/or knowledge in underwater acoustics. Most of these measurements exist in the form of gray literature, e.g., [56], and few of them have been peer-reviewed or published in peer-reviewed journals. Therefore, the quality of some sound source measurements is questionable and should be evaluated further.

\subsection{Sound Propagation Models}

Although numerous models exist for underwater sound propagation [69], the majority of these models assume that the source is in the open water. However, sources from some of the regulated activities occur within sediment or structures (e.g., confined underwater detonations) or are coupled with the sediment (e.g., DTH pile installation). The authors are unaware of an available propagation model for these sources, despite the increasing use of these sources in recent years.

For the majority of sources that are used in a water column, the existing propagation model commonly used by the regulatory community is a simple spreading model with a transmission loss coefficient of 20 or 15, depending on the source. Given that underwater sound propagation is almost always a complex process that involves bathymetry and topography of the location, substrate layers and types, temperature and salinity profiles of the water column, sea surface conditions, and the frequency spectrum of the source, sophisticated numerical modeling typically is required to obtain the reasonably accurate results needed for impact assessments.

Although many of the sophisticated numerical propagation models are derived from well-established propagation theories [129], the implementation of these models is beyond the expertise of the regulatory community due to the lack of necessary technical skills within the agencies. For example, high-level programming languages such as MATLAB or Octave are not among the standard software used by the U.S. regulatory community for conducting impact assessments.

Given these resource and technical limitations, it is beneficial to develop relatively simple numerical models that can be incorporated into an Excel spreadsheet format. For example, the U.S. National Marine Fisheries Service has developed a simple spreadsheet tool that incorporates the frequency of absorption and beam width for determining sound propagation and estimating the distances at which behavioral harassment could occur in marine mammals [130].

In another example, a damped cylindrical spreading (DCS) model-based spreadsheet, or DCSiE, was recently developed with funding from the BOEM to estimate the distances of certain received sound levels from impact pile driving for offshore wind turbine installations [131]. This spreadsheet tool incorporates information related to bathymetry and the substrate type, in addition to the measured sound level at a reference distance (typically, no less than three times the water depth at the source). It is based on a reasonably simple but more accurate DCS model [132-134]. To implement DCSiE properly for estimating impact zones, one must have an understanding of the sediment composition and the layering of those sediments (including the sediment porosity and particle size) in the project area. Unfortunately, these data are lacking in most regions and are not routinely described when pile-driving measurements are collected. In addition, a comparable sound propagation model for vibratory pile driving and removal and DTH pile installation currently does not exist. 
Although these spreadsheet tools can perform simple propagation modeling to a certain degree, they cannot replace sophisticated numerical models that are commonly used by the underwater acoustics community. To address such deficiencies, a standalone software package that does not require programming skills needs to be developed for the regulatory community.

\subsection{Statistical Detection Models}

None of the impact assessment tools for underwater sound currently address statistical signal detection at the receiver. The received level at the animal is therefore considered the level of exposure. Such an approach generally is acceptable when assessing the PTS or temporary threshold shift (TTS), as most data on those effects are based on direct measurements at the animals. However, they may not be accurate for quantitatively addressing behavioral disturbances and acoustic masking. Most research on marine animal audiograms and hearing thresholds is conducted in the absence of background sound or at very low ambient conditions with a higher signal-to-noise ratio than is typical in the marine environment. Only a few studies have addressed signal detection in the presence of noise, which could elucidate detection thresholds of some marine mammal species, e.g., [135-137] and review [138]. The authors are not aware of any such studies in species other than marine mammals. Although the detection theory falls within the fields of auditory physiology and behavioral psychology, the information from such studies is critical in the application of underwater acoustics to impact the assessments of sound. The lack of information on the auditory detection thresholds under various noise conditions by many marine species makes it impossible to conduct assessments of masking using the well-established statistical detection theory with ROC curves [5].

\subsection{Needs for Chronic Impact Assessment and Soundscape Analyses}

Despite the recent progress in understanding the impacts of chronic low-intensity sound on marine life (e.g., [83]), most of the regulatory community has been slow to implement the associated analyses. For example, shipping noises receive relatively little consideration during conservation planning and regulatory management. One of the reasons appears to be that the adverse effects from the low-intensity sound are difficult to quantify on a project and area basis, which is the main mechanism underpinning the various regulations. Therefore, models that can quantify fine-scale and project-specific impacts from low-intensity sound exposure should be developed. These models would be able to assess the energetic cost to marine life from sound exposure in the form of behavioral modification, changes in vocalizations and echolocation, communication masking, habitat displacement, and increased stress levels.

Another "low-level" impact that has received little consideration is reverberationspecifically, the reverberation field between intense intermittent sounds due to multipath propagation [139-141]. It has been suggested that the elevated background sound levels from reverberation have the potential to mask vital marine mammal acoustic cues [142]. However, there are few studies that provide quantitative data on the threshold level associated with auditory masking [143].

In addition, further studies are needed to investigate how the soundscape changes as a result of long- and short-term habitat modifications, which may affect certain species and, in turn, set off a cascade through various trophic levels and affect the ecosystem as a whole. While most of the questions being addressed lie in the field of ecoacoustics, the technical capability required to analyze large amounts of acoustic data that are being collected continuously by many global observation networks is a critical need to be addressed [144-146].

\subsection{Needs for Expertise and Knowledge within the Regulatory Community}

Last, but not least, advancements in the knowledge of underwater acoustics and its applications are not possible without a regulatory community that is well-versed in 
underwater acoustics. Since assessing acoustic impacts on marine life is an interdisciplinary field that involves physical acoustics, oceanography, and biology, scientifically sound environmental policy and conservation measures can only be developed through a solid understanding of the scientific principles within these fields. Specifically, the knowledge, skills, and expertise in performing and evaluating numerical source and propagation models; acoustic measurements; and exposure and impact models are key areas where gaps currently exist. It is imperative for regulatory agencies to integrate professional physical acousticians into their hierarchy, rather than relying on policy experts that lack formal education in and an understanding of physics, mathematics, or engineering. As the renowned acoustician Dr. Allan D. Pierce stated, "a deep understanding of acoustical principles is not acquired by superficial efforts" [147].

\section{Conclusions}

The field of the environmental conservation that addresses the impacts of underwater sound on marine life has advanced considerably over the past half-century. Although one of the initial concerns involved ever-increasing ocean ambient impacts on the communication space of baleen whales [11], the field advanced most readily when acute impacts from ATOC sources, seismic air guns, and military sonar were investigated $[17,27,34]$. The environmental impact assessments of these sound sources were assisted largely by knowledge within the field of underwater acoustics, e.g., [29,39,45].

Over the years, assessing the impacts of underwater sound has gradually evolved into a research area with its own unique definition of acoustic parameters, sound sources, propagation modeling, and measures of biological impacts, e.g., [51,52,60]. Besides addressing the direct and acute impacts of sound, which is largely under the purview of natural resource agencies that implement various regulatory statutes and measures [49-52,54], recent developments in this field include research that addresses the overall acoustic environment. These new studies have broadened the scope of the relatively narrow-focused field that only addressed acute impacts into the emergent subfield of ecoacoustics and soundscape ecology $[85,86]$. Holistic approaches for studying underwater sound in relation to marine life allow for the assessment of the overall ecosystem health, which includes an acoustic component, and of certain elements that have long-term and chronic adverse effects on marine life (e.g., low-intensity but pervasive sound from ships).

As with all emerging scientific fields, many information gaps still exist and likely will exist for the foreseeable future. Sound characteristics of many known and novel emerging anthropogenic sound sources have yet to be assessed and validated. Data on sediment composition and associated layering are lacking in many regions, which compromises the integrity and accuracy of any sophisticated sound propagation model. Sound propagation modeling, though firmly established within the underwater acoustics field, needs to be made accessible to the regulatory community, which is largely composed of conservation biologists and environmental policy specialists. Simple analytical computational methods and/or standalone software that does not require programming skills are desirable and need to be developed for regulators to conduct impact assessments. Finally, prioritizing the hiring of scientists who have formal educations in physics, mathematics, or engineering to co-lead or co-manage environmental impact assessments is essential to forming scientifically sound policy and conservation measures that minimize the impacts of underwater sound on marine life.

Author Contributions: Conceptualization: S.G. and T.B.; writing—original draft: S.G. and T.B.; and review and revisions: S.G., T.B., and J.V. All authors have read and agreed to the published version of the manuscript.

Funding: This research received no external funding.

Institutional Review Board Statement: Not applicable.

Informed Consent Statement: Not applicable. 
Acknowledgments: The authors thank Peter Thomas for a thorough review of and comments on this manuscript. The authors also appreciate the constructive comments from the three anonymous reviewers.

Conflicts of Interest: The authors declare no conflict of interest.

\section{References}

1. Scammon, C.M. The Marine Mammals of the North-Western Coast of North America, Described and Illustrated: Together with an Account of the American Whale-Fishery; J H. Carmany and Co.: San Francisco, CA, USA, 1874.

2. Great Britain Challenger Office; Wyville, T.C.; Sie Murray, J.; Nares, G.S.; Tourle, T.F. Report on the Scientific Results of the Voyage of H. M. S. Challenger during the Years 1873-76 under the Command of Captain George, S. Nares. v.32, pt.82 (1889); Neill and Company: Edinburgh, UK, 1880. Available online: https://www.biodiversitylibrary.org/bibliography/6513\#/summary (accessed on 28 September 2020).

3. $\quad$ Cousteau, J.Y. The Silent World; Harper \& Brother Publishers: New York, NY, USA, 1953.

4. Urick, R.J. Principles of Underwater Sound, 3rd ed.; McGraw-Hill Book Company: New York, NY, USA, 1983.

5. Ainslie, M.A. Principles of Sonar Performance Modelling; Springer: Berlin/Heidelberg, Germany, 2010.

6. Schevill, W.E.; Lawrence, B. Underwater listening to the white porpoise (Delphinapterus leucas). Science 1949, 109, 143-144. [CrossRef]

7. Kellogg, W.N.; Kohler, R.; Morris, H.N. Porpoise sounds as sonar signals. Science 1953, 117, 239-243. [CrossRef]

8. Norris, K.N.; Prescott, J.H.; Asa-Dorian, P.V.; Perkins, P. An experimental demonstration of echo-location behavior in the porpoise, Tursiops truncatus (Montagu). Biol. Bull. 1961, 120, 163-176. [CrossRef]

9. Ray, C.; Watkins, W.A.; Burns, J.J. The underwater song of Erignathus (bearded seal). N. Y. Zool. Soc. 1969, 54, 79-83.

10. Payne, R.S.; McVay, S. Songs of humpback whales. Science 1971, 173, 585-597. [CrossRef] [PubMed]

11. Payne, R.; Webb, D. Orientation by means of long range acoustic signaling in baleen whales. Ann. N. Y. Acad. Sci. 1971, 188, 110-141. [CrossRef] [PubMed]

12. Doub, J.P. The Endangered Species Act: History, Implementation, Successes, and Controversies; Taylor \& Francis Group: Boca Raton, FL, USA, 2013.

13. Roman, J.; Altman, I.; Campbell, C.J.; Jasny, M.; Read, A.J.; Dunphy-Daly, M.M. The marine mammal protection act at 40: Status, recovery, and future of U.S. marine mammals. Ann. N. Y. Acad. Sci. 2013, 1286, 29-49. [CrossRef]

14. Greenwald, N.; Suckling, K.F.; Hartl, B.; Mehrhoff, L.A. Extinction and the U.S. endangered species act. PeerJ 2019,7 , e6803. [CrossRef] [PubMed]

15. National Research Council. Dolphins and the Tuna Industry; National Academies Press: Washington, DC, USA, 1992.

16. Moore, J.E.; Wallace, B.P.; Lewison, R.L.; Žydelis, R.; Cox, T.M.; Crowder, L.B. A review of marine mammal, sea turtle and seabird bycatch in USA fisheries and the role of policy in shaping management. Mar. Policy 2009, 33, 435-451. [CrossRef]

17. Richardson, W.J.; Wells, R.S.; Würsig, B. Project rationale, design and summary. In Disturbance Responses and Distribution of Bowhead Whales Balaena Mysticetus in the Eastern Beaufort Sea; Richardson, W.J., Ed.; Minerals Management. Service: Reston, VA, USA, 1984

18. Richardson, W.J.; Wells, R.S.; Würsig, B. Disturbance responses of bowheads. In Behavior, Disturbance Responses and Distribution of Bowhead Whales Balaena Mysticetus in the Eastern Beaufort Sea; Richardson, W.J., Ed.; Minerals Management Service: Reston, VA, USA, 1984.

19. Richardson, W.J.; Fraker, M.A.; Würsig, B.; Wells, R.S. Behaviour of bowhead whales Balaena mysticetus summering in the Beaufort Sea: Reactions to industrial activities. Biol. Conserv. 1985, 32, 195-230. [CrossRef]

20. Richardson, W.J.; Würsig, B.; Greene, C.R., Jr. Reactions of bowhead whales, Balaena mysticetus, to seismic exploration in the Canadian Beaufort Sea. J. Acoust. Soc. Am. 1986, 79, 1117-1128. [CrossRef] [PubMed]

21. Richardson, W.J.; Greene, C.R., Jr.; Hanna, J.S.; Koski, W.R.; Miller, G.W.; Patenaude, N.J.; Smultea, M.A. Acoustic Effects of Oil Production Activities on Bowhead and White Whales Visible during Spring Migration Near Pt. Barrow, Alaska-1991 and 1994 Phases: Sound Propagation and Whale Responses to Playbacks of Icebreaker Noise; Minerals Management Service: Herndon, VA, USA, 1995.

22. Cohen, J. Was underwater "shot" harmful to the whales? Science 1991, 252, 912-914. [CrossRef] [PubMed]

23. Munk, W.H.; Spindel, R.C.; Baggeroer, A.; Birdsall, T.G. The Heard Island feasibility test. J. Acoust. Soc. Am. 1994, 96, $2330-2342$. [CrossRef]

24. Munk, W.H.; Worcester, P. Ocean Acoustic Tomography; Cambridge University Press: Cambridge, UK, 1995.

25. Dushaw, B.; Worcester, P.F.; Munk, W.H.; Spindel, R.C.; Mercer, J.A.; Howe, B.M.; Metzger, K.; Birdsall, T.G.; Andrew, R.K.; Dzieciuch, M.A.; et al. A decade of acoustic thermometry in the North Pacific Ocean. J. Geophys. Res. Space Phys. 2009, 114, C07021. [CrossRef]

26. Howe, B.M.; Anderson, S.G.; Baggeroer, A.; Colosi, J.A.; Hardy, K.R.; Horwitt, D.; Karig, F.W.; Leach, S.; Mercer, J.A.; Metzger, K., Jr. Instrumentation for the Acoustic Thermometry of Ocean Climate (ATOC) prototype Pacific Ocean network. In Challenges of our Changing Global Environment, Proceedings of the OCEANS 1995 MTS/IEEE, San Diego, CA, USA, 9-12 October 1995; IEEE: New York, NY, USA, 1995; Volume 3, pp. 1483-1500.

27. Bowles, A.E.; Smultea, M.; Würsig, B.; DeMaster, D.P.; Palka, D. Relative abundance and behavior of marine mammals exposed to transmissions from the Heard Island Feasibility test. J. Acoust. Soc. Am. 1994, 96, 2469-2484. [CrossRef] 
28. National Research Council. Low-Frequency Sound and Marine Mammals: Current Knowledge and Research Needs; National Academies Press: Washington, DC, USA, 1994.

29. National Research Council. Marine Mammals and Low-Frequency Sound: Progress Since 1994; National Academies Press: Washington, DC, USA, 2000.

30. Au, W.W.L.; Nachtigall, P.E.; Pawloski, J.L. Acoustic effects of the ATOC signal $(75 \mathrm{~Hz}, 195 \mathrm{~dB})$ on dolphins and whales. J. Acoust. Soc. Am. 1997, 101, 2973-2977. [CrossRef]

31. Klimley, A.P.; Beavers, S.C. Playback of acoustic thermometry of ocean climate (ATOC) -like signal to bony fishes to evaluate phonotaxis. J. Acoust. Soc. Am. 1998, 104, 2506-2510. [CrossRef]

32. Costa, D.P.; Crocker, D.E.; Gedamke, J.; Webb, P.M.; Houser, D.S.; Blackwell, S.B.; Waples, D.; Hayes, S.A.; Le Boeuf, B.J. The effect of a low-frequency sound source (acoustic thermometry of the ocean climate) on the diving behavior of juvenile northern elephant seals Mirounga angustirostris. J. Acoust. Soc. Am. 2003, 113, 1155-1165. [CrossRef]

33. Simmonds, M.P.; López-Jurado, L.F. Whales and the military. Nature 1991, 351, 448. [CrossRef]

34. Frantzis, A. Does acoustic testing strand whales? Nature 1998, 392, 29. [CrossRef]

35. Evans, D.L.; England, G.R. Joint Interim Report Bahamas Marine Mammal Stranding Event of 15-16 March 2000; National Oceanic and Atmospheric Administration: Silver Spring, MD, USA, 2001.

36. D'Amico, A.; Gisiner, R.C.; Ketten, D.R.; Hammock, J.A.; Johnson, C.; Tyack, P.L.; Mead, J. Beaked Whale strandings and naval exercises. Aquat. Mamm. 2009, 35, 452-472. [CrossRef]

37. Filadelfo, R.; Mintz, J.; Michlovich, E.; D'Amico, A.; Tyack, P.L.; Ketten, D.R. Correlating military sonar use with beaked whale mass strandings: What do the historical data show? Aquat. Mamm. 2009, 35, 435-444. [CrossRef]

38. Fernández, A.; Sierra, E.; Martín, V.; Méndez, M.; Sacchinni, S.; de Quirós, Y.B.; Andrada, M.; Rivero, M.; Quesada, O.; Tejedor, M.; et al. Last "atypical" beaked whales mass stranding in the Canary Islands (July 2004). J. Mar. Sci. Res. Deve. 2012, 2, 3. [CrossRef]

39. National Research Council. Ocean Noise and Marine Mammals; The National Academies Press: Washington, DC, USA, 2003.

40. National Research Council. Marine Mammal Population and Ocean Noise: Determining When Noise Causes Biologically Significant Effects; The National Academies Press: Washington, DC, USA, 2005.

41. National Research Council. Approaches to Understanding the Cumulative Effects of Stressors on Marine Mammals; National Academies Press: Washington, DC, USA, 2017.

42. Williams, R.; Wright, A.J.; Ashe, E.; Blight, L.K.; Bruintjes, R.; Canessa, R.; Clark, C.W.; Cullis-Suzuki, S.; Dakin, D.; Erbe, C.; et al. Impacts of anthropogenic noise on marine life: Publication patterns, new discoveries, and future directions in research and management. Ocean Coast. Manag. 2015, 115, 17-24. [CrossRef]

43. Hawkins, A.D.; Popper, A.N. A sound approach to assessing the impact of underwater noise on marine fishes and inverte-brates. ICES J. Mar. Sci. 2016, 74, 635-651. [CrossRef]

44. Faulkner, R.C.; Farcas, A.; Merchant, N.D. Guiding principles for assessing the impact of underwater noise. J. Appl. Ecol. 2018, 55, 2531-2536. [CrossRef]

45. Richardson, W.J.; Greene, C.R., Jr.; Malme, C.I.; Thomson, D.H. Marine Mammals and Noise; Academic Press: San Diego, CA, USA, 1995.

46. Chapman, D.M.F.; Ellis, D.D. The elusive decibel: Thoughts on sonars and marine mammals. Can. Acoust. 1998, $26,29-31$.

47. Nedelec, S.L.; Campbell, J.; Radford, A.N.; Simpson, S.D.; Merchant, N.D. Particle motion: The missing link in underwater acoustic ecology. Methods Ecol. Evol. 2016, 7, 836-842. [CrossRef]

48. Popper, A.N.; Hawkins, A.D. The importance of particle motion to fishes and invertebrates. J. Acoust. Soc. Am. 2018, 143, 470-488. [CrossRef]

49. National Marine Fisheries Service. Technical Guidance for Assessing the Effects of Anthropogenic Sound on Marine Mammal Hearing: Underwater Acoustic Thresholds for Onset of Permanent and Temporary Threshold Shifts; National Oceanic and Atmospheric Administration: Silver Spring, MD, USA, 2016; p. 178.

50. National Marine Fisheries Service. Revisions to: Technical Guidance for Assessing the Effects of Anthropogenic Sound on Marine Mammal Hearing Underwater Thresholds for Onset of Permanent and Temporary Threshold Shifts; National Oceanic and Atmospheric Administration: Silver Spring, MD, USA, 2018; p. 167. Available online: https://www.fisheries.noaa.gov/national/marinemammal-protection/marine-mammal-acoustic-technical-guidance (accessed on 17 November 2020).

51. Southall, B.L.; Finneran, J.J.; Reichmuth, C.; Nachtigall, P.E.; Ketten, D.R.; Bowles, A.E.; Ellison, W.T.; Nowacek, D.P.; Tyack, P.L. Marine mammal noise exposure criteria: Updated scientific recommendations for residual hearing effects. Aquat. Mamm. 2019, 45, 125-232, Erratum in 2019, 45, 569-572. [CrossRef]

52. Finneran, J.J.; Jenkins, A.K. Criteria and Thresholds for U.S. Navy Acoustic and Explosive Effects Analysis (Phase III); SSC Pacific: San Diego, CA, USA, 2017.

53. Popper, A.N.; Hawkins, A.D.; Fay, R.R.; Mann, D.A.; Bartol, S.; Carlson, T.J.; Coombs, S.; Ellison, W.T.; Gentry, R.L.; Halvorsen, M.B.; et al. Sound Exposure Guidelines for Fishes and Sea Turtles: A Technical Report Prepared by ANSI-Accredited Standards Committee S3/SC1 and Registered with ANSI; Springer Nature: Berlin/Heidelberg, Germany, 2014.

54. Scholik-Schlomer, A.R. Where the decibels hit the water: Perspectives on the application of science to real-world underwater noise and marine protected species issues. Acoust. Today 2015, 11, 36-44.

55. Madsen, P.T. Marine mammals and noise: Problems with root mean square sound pressure levels for transients. J. Acoust. Soc. Am. 2005, 117, 3952-3957. [CrossRef] 
56. Buehler, D.; Oestman, R.; Reyff, J.; Pommerenck, K.; Mitchell, B. Technical Guidance for Assessment and Mitigation of the Hydroacoustic Effects of Pile Driving on Fish; California Department of Transportation: Sacramento, CA, USA, 2015. Available online: http:/ / website.dot.ca.gov/env/bio/docs/biotech-guidance-hydroacoustic-effects-110215.pdf (accessed on 28 September 2020).

57. Guan, S.; Miner, R. Underwater noise characterization of down-the-hole pile driving activities off Biorka Island, Alaska. Mar. Pollut. Bull. 2020, 160, 111664. [CrossRef]

58. Wenz, G.M. Acoustic ambient noise in the ocean: Spectra and sources. J. Acoust. Soc. Am. 1962, 34, 1936-1956. [CrossRef]

59. Urick, R.J. Ambient Noise in the Sea; Naval Sea Systems Command, Department of the Navy: Washington, DC, USA, 1984.

60. Southall, B.L.; Bowles, A.E.; Ellison, W.T.; Finneran, J.J.; Gentry, R.L.; Greene, C.R., Jr.; Kastak, D.K.; Ketten, D.R.; Miller, J.H.; Nachtigall, P.E.; et al. Marine mammal noise-exposure criteria: Initial scientific recommendations. Aquat. Mamm. 2007, 33, 411-521. [CrossRef]

61. Martin, S.B.; Lucke, K.; Barclay, D.R. Techniques for distinguishing between impulsive and non-impulsive sound in the context of regulating sound exposure for marine mammals. J. Acoust. Soc. Am. 2020, 147, 2159-2176. [CrossRef] [PubMed]

62. National Marine Fisheries Service. Manual for Optional USER SPREADSHEET Tool (Version 2.2, December) for: 2018 Revision to: Technical Guidance for Assessing the Effects of Anthropogenic Sound on Marine Mammal Hearing (Version 2.0): Underwater Thresholds for Onset of Permanent and Temporary Threshold Shifts; National Oceanic and Atmospheric Administration: Silver Spring, MD, USA, 2020. Available online: https://media.fisheries.noaa.gov/2020-12/User_Manual\%20_DEC_2020_508.pdf? null (accessed on 22 December 2020).

63. Ireland, D.; Rodrigues, R.; Hannay, D.; Jankowski, M.; Hunter, A.; Patterson, H.; Haley, B.; Funk, D.W. Marine Mammal Monitoring and Mitigation during Open Water Seismic Exploration by ConocoPhillips Alaska Inc. in the Chukchi Sea, July-October 2006: 90-Day Report; Technical Report Prepared for Shell Offshore, Inc.; National Marine Fisheries Service; U.S. Fish and Wildlife Service; LGL Research Associates, Inc.: Anchorage, AK, USA, 2007.

64. Ireland, D.S.; Rodrigues, R.; Funk, D.; Koski, W.; Hannay, D. Marine Mammal Monitoring and Mitigation during Open Water Seismic Exploration by Shell Offshore Inc. in the Chukchi and Beaufort Seas, July-October 2008: 90-Day Report; Technical Report Prepared for Shell Offshore Inc.; National Marine Fisheries Service; U.S. Fish and Wildlife Service; LGL Research Associates, Inc.: Anchorage, AK, USA, 2009.

65. Funk, D.; Hannay, D.; Ireland, D.; Rodrigues, R.; Koski, W. Marine Mammal Monitoring and Mitigation during Open Water Seism Offshore Inc. In the Chukchi and Beaufort Seas, July-November 2007: 90-Day Report; Technical Report Prepared for Shell Offshore Inc.; National Marine Fisheries Service; U.S. Fish and Wildlife Service; LGL Research Associates, Inc.: Anchorage, AK, USA, 2008.

66. Reiser, C.M.; Funk, D.W.; Rodrigues, R.; Hannay, D. Marine Mammal Monitoring and Mitigation during Open Water Seismic Exploration by Shell Offshore, Inc. in the Alaskan Chukchi Sea, July-October 2009: 90-Day Report; Technical Report Prepared for Shell Offshore Inc.; National Marine Fisheries Service; U.S. Fish and Wildlife Service; LGL Research Associates, Inc.: Anchorage, AK, USA, 2010.

67. Reiser, C.M.; Funk, D.W.; Rodrigues, R.; Hannay, D. Marine Mammal Monitoring and Mitigation during Marine Geophysical Surveys by Shell Offshore, Inc. In the Alaskan Chukchi and Beaufort seas, July-October 2010: 90-Day Report; Technical Report Prepared for Shell Offshore Inc.; National Marine Fisheries Service; U.S. Fish and Wildlife Service; LGL Research Associates, Inc.: Anchorage, AK, USA, 2011.

68. Denes, S.L.; Zeddies, D.G.; Weirathmueller, M.M. Turbine Foundation and Cable Installation at South Fork Wind Farm: Underwater Acoustic Modeling of Construction Noise; Technical Report for Jacobs Engineering Group Inc. JASCO Applied Sciences (USA) Inc.: Silver Spring, MD, USA, 2020.

69. Etter, P.C. Underwater Acoustic Modeling and Simulation, 4th ed.; CRC Press: Boca Raton, FL, USA, 2013.

70. Medwin, H.; Clay, C.S. Fundamentals of Acoustical Oceanography; Academic Press: San Diego, CA, USA, 2008.

71. Au, W.W.L.; Hastings, M.C. Principles of Marine Bioacoustics; Springer: New York, NY, USA, 2008.

72. Lurton, X. An Introduction to Underwater Acoustics—Principles and Applications, 2nd ed.; Springer: Chichester, UK, 2010.

73. Erbe, C. Underwater Acoustics: Noise and the effects on marine mammals. Pocket Handb. 2011, 164, 9-10.

74. National Marine Fisheries Service. Takes of marine mammals incidental to specified activities; Taking marine mammals incidental to the transit protection program pier and support facilities project at Naval Base Kitsap Bangor, Washington. Fed. Reg. 2020, 85, $48206-48225$.

75. Austin, M.; Denes, S.; MacDonnell, J.; Warner, G. Hydroacoustic Monitoring Report: Anchorage Port Modernization Project Test Pile Program. Version 3.0; Technical Report for Kiewit Infrastructure West Co. JASCO Applied Sciences (Alaska) Inc.: Anchorage, AK, USA, 2016.

76. National Marine Fisheries Service. Taking and importing marine mammals; Taking marine mammals incidental to the U.S. Navy training and testing activities in the Hawaii-Southern California training and testing study area. Fed. Reg. 2018, 83, 66846-67031.

77. National Marine Fisheries Service. Takes of marine mammals incidental to specified activities; Taking marine mammals incidental to construction of the Vineyard Wind Offshore Wind Project. Fed. Reg. 2019, 84, 18346-18381.

78. Finneran, J.J. Noise-induced hearing loss in marine mammals: A review of temporary threshold shift studies from 1996 to $2015 . J$. Acoust. Soc. Am. 2015, 138, 1702-1726. [CrossRef] [PubMed]

79. Houser, D.S. A method for modeling marine mammal movement and behavior for environmental impact assessment. IEEE J. Ocean. Eng. 2006, 31, 76-81. [CrossRef] 
80. Blackstock, S.A.; Fayton, J.O.; Hulton, P.H.; Moll, T.E.; Jenkins, K.; Kotecki, S.; Henderson, E.; Rider, S.; Martin, C.; Bowman, V. Quantifying Acoustic Impacts on Marine Mammals and Sea Turtles: Methods and Analytical Approach for Phase III Training and Testing; Space and Naval Warfare Systems Center Pacific: San Diego, CA, USA, 2017.

81. Bassett, C.; Polagye, B.; Holt, M.; Thomson, J. A vessel noise budget for Admiralty Inlet, Puget Sound, Washington (USA). J. Acoust. Soc. Am. 2012, 132, 3706-3719. [CrossRef] [PubMed]

82. McKenna, M.F.; Ross, D.; Wiggins, S.M.; Hildebrand, J.A. Underwater radiated noise from modern commercial ships. J. Acoust. Soc. Am. 2012, 131, 92-103. [CrossRef]

83. Erbe, C.; Marley, S.A.; Schoeman, R.P.; Smith, J.N.; Trigg, L.E.; Embling, C.B. The effects of ship noise on marine mammals-A Review. Front. Mar. Sci. 2019, 6, 606. [CrossRef]

84. Howe, B.M.; Miksis-Olds, J.; Rehm, E.; Sagen, H.; Worcester, P.F.; Haralabus, G. Observing the Oceans Acoustically. Front. Mar. Sci. 2019, 6, 426. [CrossRef]

85. Farina, A. Soundscape Ecology: Principles, Patterns, Methods and Applications; Springer: New York, NY, USA, 2014.

86. Farina, A.; Gage, S.H. Ecoacoustics: The Ecological Role of Sound; John Wiley and Sons: Hoboken, NJ, USA, 2017.

87. Marine Mammal Commission. Comments and Recommendations from the U.S. Marine Mammal Commission on Fish and Wildlife Service's Proposed Issuance of a Regulation to Hilcorp Alaska, Harvest Alaska, and the Alaska Gasline Development Corporation; Marine Mammal Commission: Bethesda, MD, USA, 2019. Available online: https://www.mmc.gov/wp-content/uploads/19-04-18 -Putnam-Cook-Inlet-OG-activities-proposed-ITR.pdf (accessed on 10 January 2021).

88. Marine Mammal Commission. Comments and Recommendations from the U.S. Marine Mammal Commission on Fish and Wildlife Service's Proposed Issuance of Incidental Harassment Authorizations to the City and Borough of Sitka and Duck Point Development II, LLC.; Marine Mammal Commission: Bethesda, MD, USA, 2019. Available online: https://www.mmc.gov/wp-content/uploads/19-0724-Lemons-and-Putnam-CBS-and-DPD-IHAs.pdf (accessed on 10 January 2021).

89. Marine Mammal Commission. Comments and Recommendations from the U.S. Marine Mammal Commission on National Marine Fisheries Service's Proposed Issuance of an Incidental Harassment Authorization to Alaska Marine Lines; Marine Mammal Commission: Bethesda, MD, USA, 2020. Available online: https://www.mmc.gov/wp-content/uploads/20-01-09-Harrison-Alaska-MarinesLine-IHA-003.pdf (accessed on 10 January 2021).

90. Marine Mammal Commission. Comments and Recommendations from the U.S. Marine Mammal Commission on National Marine Fisheries Service's Proposed Issuance of an Incidental Harassment Authorization to the National Science Foundation's Office of Polar Programs to Take Marine Mammals Incidental to Conducting a Marine Geophysical Survey in the Amundsen Sea in February 2020. 21 January 2020; Marine Mammal Commission: Bethesda, MD, USA, 2020. Available online: https://www.mmc.gov/wp-content/uploads/20-0121-Harrison-NSF-Amundsen-Sea-IHA.pdf (accessed on 10 January 2021).

91. Marine Mammal Commission. Comments and Recommendations from the U.S. Marine Mammal Commission on National Marine Fisheries Service's Proposed Issuance of an Incidental Harassment Authorization to Port of Alaska to take Marine Mammals Incidental to Construction of a New Petroleum and Cement Terminal in Anchorage, Alaska. 23 January 2020; Marine Mammal Commission: Bethesda, MD, USA, 2020. Available online: https://www.mmc.gov/wp-content/uploads/20-01-23-Harrison-POA-IHAs.pdf (accessed on 10 January 2021).

92. Marine Mammal Commission. Comments and Recommendations from the U.S. Marine Mammal Commission on National Marine Fisheries Service's Proposed Issuance of an Incidental Harassment Authorization to the Power Systems \& Supplies of Alaska to Take Marine Mammals Incidental to Dock Construction in Ketchikan, Alaska. 23 March 2020; Marine Mammal Commission: Bethesda, MD, USA, 2020. Available online: https:/ / www.mmc.gov/wp-content/uploads/20-03-23-Harrison-PSSA-IHA.pdf (accessed on 10 January 2021).

93. Marine Mammal Commission. Comments and Recommendations from the U.S. Marine Mammal Commission on National Marine Fisheries Service's Proposed Issuance of an Incidental Harassment Authorization to Hampton Roads Connector Partners to Take Marine Mammals Incidental to Conducting Construction Activities for the Hampton Roads Bridge-Tunnel Expansion Project in Virginia. 20 April 2020; Marine Mammal Commission: Bethesda, MD, USA, 2020. Available online: https://www.mmc.gov/wp-content/uploads/ 20-04-20-Harrison-HRCP-IHA.pdf (accessed on 10 January 2021).

94. Marine Mammal Commission. Comments and Recommendations from the U.S. Marine Mammal Commission on National Marine Fisheries Service's Proposed Issuance of an Incidental Harassment Authorization to the Gastineau Channel Historical Society to Take Marine Mammals Incidental to Constructing a Mooring Float Near Juneau, Alaska. 24 April 2020; Marine Mammal Commission: Bethesda, MD, USA, 2020. Available online: https:/ / www.mmc.gov/wp-content/uploads/20-04-24-Harrison-GCHS-IHA.pdf (accessed on 10 January 2021).

95. Marine Mammal Commission. Comments and Recommendations from the U.S. Marine Mammal Commission on National Marine Fisheries Service's Proposed Issuance of an Incidental Harassment Authorization to the City and County of San Francisco to Take Marine Mammals Incidental to Conducting Various Construction Activities on Treasure Island in San Francisco Bay, California. 29 June 2020; Marine Mammal Commission: Bethesda, MD, USA, 2020. Available online: https://www.mmc.gov/wp-content/uploads/20-0629-Harrison-City-of-SF-IHA.pdf (accessed on 10 January 2021).

96. Marine Mammal Commission. Comments and Recommendations from the U.S. Marine Mammal Commission on National Marine Fisheries Service's Proposed Issuance of an Incidental Harassment Authorization to Lamont-Doherty Earth Observatory to Take Marine Mammals Incidental to Conducting a Marine Geophysical Survey in the Bering Sea and North Pacific Ocean. 13 August 2020; Marine Mammal Commission: Bethesda, MD, USA, 2020. Available online: https://www.mmc.gov/wp-content/uploads/20-08-13 -Harrison-LDEO-Aleutian-IHA.pdf (accessed on 10 January 2021). 
97. Dazey, E.; McIntosh, B.; Brown, S.; Dudzinski, K.M. Assessment of underwater anthropogenic noise associated with construction activities in Bechers Bay, Santa Rosa Island, California. J. Environ. Prot. 2012, 3, 1286-1294. [CrossRef]

98. Denes, S.L.; Warner, G.J.; Austin, M.E.; MacGillivray, A.O. Hydroacoustic Pile Driving Noise Study-Comprehensive Report; JASCO Applied Sciences Inc.: Anchorage, AK, USA, 2016; Available online: http:/ /www.dot.state.ak.us/stwddes/research/assets/pdf/ 4000-135.pdf (accessed on 10 January 2021).

99. Denes, S.; Vallarta, J.; Zeddies, D. Sound Source Characterization of Down-the-Hole Hammering: Thimble Shoal, Virginia; JASCO Applied Sciences (USA) Inc.: Silver Spring, MD, USA, 2019. Available online: https://www.fisheries.noaa.gov/webdam/ download/105110147 (accessed on 10 January 2021).

100. Reyff, J. Review of Down-the-Hole Rock Socket Drilling Acoustic Data Measured for White Pass and Yukon Route (WPEYR) Mooring Dolphins; Illingworth \& Rodkin, Inc.: Cotati, CA, USA, 2020; p. 8.

101. Reyff, J.; Heyvaert, C. White Pass and Yukon Railroad Mooring Dolphin Installation: Pile Driving and Drilling Sound Source Verifica-tion; Illingworth \& Rodkin, Inc.: Cotati, CA, USA, 2019. Available online: https://www.fisheries.noaa.gov/webdam/download/1047 95528 (accessed on 28 September 2020).

102. Deng, Z.D.; Southall, B.L.; Carlson, T.J.; Xu, J.; Martinez, J.J.; Weiland, M.A.; Ingraham, J.M. 200 kHz commercial sonar systems generate lower frequency side lobes audible to some marine mammals. PLoS ONE 2014, 9, e95315. [CrossRef]

103. Hastie, G.D.; Donovan, C.; Götz, T.; Janik, V.M. Behavioral responses by grey seals (Halichoerus grypus) to high frequency sonar. Mar. Pollut. Bull. 2014, 79, 205-210. [CrossRef]

104. Cholewiak, D.M.; DeAngelis, A.I.; Palka, D.; Corkeron, P.J.; Van Parijs, S.M. Beaked whales demonstrate a marked acoustic response to the use of shipboard echosounders. R. Soc. Open Sci. 2017, 4, 170940. [CrossRef]

105. Varghese, H.K.; Miksis-Olds, J.L.; DiMarzio, N.; Lowell, K.; Linder, E.; Mayer, L.; Moretti, D. The effect of two 12 kHz multibeam mapping surveys on the foraging behavior of Cuvier's beaked whales off of southern California. J. Acoust. Soc. Am. 2020, 147, 3849-3858. [CrossRef]

106. Crocker, S.E.; Fratantonio, F.D. Characteristics of Sounds Emitted during High-Resolution Marine Geophysical Surveys; Naval Undersea Warfare Center Division: Newport, RI, USA, 2016.

107. LGL Ecological Research Associates Inc. Marine Acoustics Inc. Environmental Assessment of Marine Vibroseis; Technical Report for Joint Industry Programme, E \& P Sound and Marine Life; International Association of Oil \& Gas Producers: London, UK, 2011; p. 207.

108. CSA. Quieting Technologies for Reducing Noise during Seismic Surveying and Pile Driving Workshop; Bureau of Ocean Energy Management: Herdon, VA, USA, 2014.

109. Long, A.; Tenghamn, R. Marine vibrator concepts for modern seismic challenges. ASEG Ext. Abstr. 2018, 2018, 1-4. [CrossRef]

110. Orji, O.; Oscarsson-Nagel, M.D.C.; Söllner, W.; Trætten, Ø.; Armstrong, B.; Nams, D.; Yeatman, P. Marine vibrator source: Modular projector system. In SEG Technical Program Expanded Abstracts 2019; Bevc, D., Nedorub, O., Eds.; Society of Exploration Geophysicists: Tulsa, OK, USA, 2019. [CrossRef]

111. Arons, A.B. Secondary pressure pulses due to gas globe oscillation in underwater explosions. II. Selection of adiabatic parameters in the theory of oscillation. J. Acoust. Soc. Am. 1948, 20, 277-282. [CrossRef]

112. Cole, R.H.; Weller, R. Underwater Explosions; Princeton University Press: Preston, NJ, USA, 1948.

113. Weston, D.E. Underwater Explosions as Acoustic Sources. Proc. Phys. Soc. 1960, 76, 233-249. [CrossRef]

114. Rogers, P.H. Weak-shock solution for underwater explosive shock waves. J. Acoust. Soc. Am. 1977, 62, 1412-1419. [CrossRef]

115. Nedwell, J.R.; Thandavamoorthy, T.S. The waterborne pressure wave from buried explosive charges: An experimental investigation. App. Acoust. 1992, 37, 1-14. [CrossRef]

116. Hall, M.V. Underwater signals from confined explosions in very shallow water. In Proceedings of the 20th International Congress Acoustics ICA 2010, Sydney, Australia, 3-27 August 2010; p. 5.

117. Beland, J.A.; Ireland, D.S.; Bisson, L.N.; Hannay, D. Marine Mammal Monitoring and Mitigation during a Marine Seismic Survey by ION Geophysical in the Arctic Ocean, October-November 2012: 90-Day Report; Technical Report for ION, Geophysical; Nature Marine Fisheries Service, and U.S. Fish and Wildfire Service; LGL Research Associates, Inc.: Anchorage, AK, USA, 2013.

118. Cate, J.R.; Smultea, M.; Blees, M.; Larson, M.; Simpson, S.; Jefferson, T.; Steckler, D. 90-Day Report of Marine Mammal Monitoring and Mitigation during a 2D Seismic Survey by TGS in the Chukchi Sea, August through October 2013; Technical Report for TGS-NOPEC Geophysical Company; National Marine Fisheries Service and U.S. Fish and Wildlife Service; ASRC Energy Services: Anchorage, AK, USA, 2014.

119. Cate, J.R.; Blees, M.; Larson, M.; Simpson, S.; Mills, R.; Cooper, R. 90-Day Report of Marine Mammal Monitoring and Mitigation during a Shallow Geohazard Survey Hilcorp in Foggy Island Bay, Alaska, July 2015; Technical Report for Hilcorp Alaska, LLC; National Marine Fisheries Service and U.S. Fish and Wildlife Service; ASRC Energy Services: Anchorage, AK, USA, 2015.

120. Laws, R.M. The Interaction of Marine Seismic Sources. Ph.D. Thesis, University of London, London, UK, 1991.

121. Laws, R.M.; Hatton, L.; Haartsen, M. Computer Modelling of Clustered Airguns. First Break 1990, 8, 331-338. [CrossRef]

122. PGS. Nucleus+: Survey Design and Modeling. 2020. Available online: https://www.pgs.com/marine-acquisition/tools-andtechniques/acquisition-solutions/technology/nucleus/ (accessed on 27 November 2020).

123. MacGillivray, A.O. Acoustic Modelling Study of Seismic Airgun Noise in Queen Charlotte Basin. Master's Thesis, University of Victoria, Victoria, BC, USA, 2006. 
124. Ainslie, M.A.; Halvorsen, M.B.; Dekeling, R.; Laws, R.M.; Duncan, A.J.; Frankel, A.S.; Heaney, K.D.; Küsel, E.T.; MacGillivray, A.; Prior, M.K.; et al. Verification of airgun sound field models for environmental impact assessment. Proc. Meet. Acoust. 2016, 27, 070018. [CrossRef]

125. Ainslie, M.A.; Laws, R.M.; Sertlek, H.Ö. International Airgun Modeling Workshop: Validation of source signature and sound propagation models—Dublin (Ireland), 16 July 2016—Problem description. IEEE J. Ocean. Eng. 2019, 44, 565-574. [CrossRef]

126. MacGillivray, A. A model for underwater sound levels generated by marine impact pile driving. Proc. Meet. Acoust. 2014, 20, 045008.

127. Lippert, S.; Nijhof, M.; Lippert, T.; Wilkes, D.; Gavrilov, A.; Heitmann, K.; Ruhnau, M.; Von Estorff, O.; Schafke, A.; Schafer, I.; et al. COMPILE-A generic benchmark case for predictions of marine pile-driving noise. IEEE J. Ocean. Eng. 2016, 41, 1061-1071. [CrossRef]

128. Jeong, C.; Manalaysay, A.; Gharti, H.N.; Guan, S.; Vignola, J. Applicability of 3D Spectral Element Method for Computing Close-Range Underwater Piling Noises. J. Theor. Comput. Acoust. 2019, 27, 1950012. [CrossRef]

129. Jensen, F.B.; Kuperman, W.A.; Porter, M.B.; Schmidt, H. Computational Ocean Acoustics, 2nd ed.; Springer: New York, NY, USA, 2010

130. National Marine Fisheries Service. Interim Recommendation for Sound Source Level and Propagation Analysis for High Resolution Geophysical (HRG) Sources; National Marine Fisheries Service: Silver Spring, MD, USA, 2020; p. 5.

131. Heaney, K.D.; Ainslie, M.A.; Halvorsen, M.B.; Seger, K.D.; Müller, R.A.J.; Nijhof, M.J.J.; Lippert, T. A Parametric Analysis and Sensitivity Study of the Acoustic Propagation for Renewable Energy Sources; U.S. Department of the Interior Bureau of Ocean Energy Management: Sterling, VA, USA, 2020; p. 165. Available online: https://espis.boem.gov/final\%20reports/BOEM_2020-011.pdf (accessed on 28 November 2020).

132. Lippert, T.; Ainslie, M.A.; Von Estorff, O. Pile driving acoustics made simple: Damped cylindrical spreading model. J. Acoust. Soc. Am. 2018, 143, 310-317. [CrossRef]

133. Müller, R.A.; Ainslie, M.A.; Halvorsen, M.B.; Lippert, T. Empirical modelling for derived metrics as function of sound exposure level in marine pile driving. J. Acoust. Soc. Am. 2018, 144, 1809. [CrossRef]

134. Ainslie, M.A.; Halvorsen, M.B.; Müller, R.A.J.; Lippert, T. Application of damped cylindrical spreading to assess range to injury threshold for fishes from impact pile driving. J. Acoust. Soc. Am. 2020, 148, 108-121. [CrossRef] [PubMed]

135. Erbe, C.; Farmer, D. Masked hearing thresholds of a beluga whale (Delphinapterus leucas) in icebreaker noise. Deep Sea Res. 1998, 45, 1373-1388. [CrossRef]

136. Branstetter, B.K.; Trickey, J.S.; Bakhtiari, K.; Black, A.; Aihara, H.; Finneran, J.J. Auditory masking patterns in bottlenose dolphins (Tursiops truncatus) with natural, anthropogenic, and synthesized noise. J. Acoust. Soc. Am. 2013, 133, 1811-1818. [CrossRef] [PubMed]

137. Cunningham, K.C.; Southall, B.L.; Reichmuth, C. Auditory sensitivity in complex listening scenarios. J. Acoust. Soc. Am. 2014, 136, 3410-3421. [CrossRef] [PubMed]

138. Erbe, C.; Reichmuth, C.; Cunningham, K.; Lucke, K.; Dooling, R. Communication masking in marine mammals: A review and research strategy. Mar. Pollut. Bull. 2016, 103, 15-38. [CrossRef]

139. Guerra, M.; Thode, A.M.; Blackwell, S.B.; Macrander, A.M. Quantifying seismic survey reverberation off the Alaskan North Slope. J. Acoust. Soc. Am. 2011, 130, 3046-3058. [CrossRef]

140. Guan, S.; Vignola, J.; Judge, J.; Turo, D. Airgun inter-pulse noise field during a seismic survey in an Arctic ultra shallow marine environment. J. Acoust. Soc. Am. 2015, 138, 3447-3457. [CrossRef] [PubMed]

141. Guan, S.; Southall, B.L.; Vignola, J.F.; Judge, J.A.; Turo, D. Sonar inter-ping noise field characterization during cetacean be-havioral response studies off southern California. Acoust. Phys. 2017, 63, 204-215. [CrossRef]

142. Clark, C.; Ellison, W.; Southall, B.; Hatch, L.; Van Parijs, S.; Frankel, A.; Ponirakis, D. Acoustic masking in marine ecosystems: Intuitions, analysis, and implication. Mar. Ecol. Prog. Ser. 2009, 395, 201-222. [CrossRef]

143. Sills, J.M.; Southall, B.L.; Reichmuth, C. The influence of temporally varying noise from seismic air guns on the detection of underwater sounds by seals. J. Acoust. Soc. Am. 2017, 141, 996-1008. [CrossRef]

144. Dugan, P.; Pourhomayoun, M.; Shiu, Y.; Paradis, R.; Rice, A.N.; Clark, C. Using high performance computing to explore large complex bioacoustic soundscapes: Case study for right whale acoustics. Procedia Comput. Sci. 2013, 20, 156-162. [CrossRef]

145. Sethi, S.S.; Jones, N.S.; Fulcher, B.D.; Picinali, L.; Clink, D.J.; Klinck, H.; Orme, C.D.L.; Wrege, P.H.; Ewers, R.M. Characterizing soundscapes across diverse ecosystems using a universal acoustic feature set. Proc. Natl. Acad. Sci. USA 2020, 117, 17049-17055. [CrossRef]

146. Shiu, Y.; Palmer, K.J.; Roch, M.A.; Fleishman, E.; Liu, X.; Nosal, E.-M.; Helble, T.; Cholewiak, D.; Gillespie, D.; Klinck, H. Deep neural networks for automated detection of marine mammal species. Sci. Rep. 2020, 10, 1-12. [CrossRef]

147. Pierce, A.D. Acoustics: An Introduction to Its Physical Principles and Applications; Acoustical Society of America: Woodbury, NW, USA, 1991. 